\title{
Isolation of Pyran Composition and Anti-Parkinson's Activity of euphorbia Cyathophora
}

\section{Ruby $\mathbf{S}^{*}$, Jaykar B}

Department of Pharmaceutical Chemistry, Vinayaka Mission's College of Pharmacy, - Vinayaka Mission's Research Foundation, (deemed to be university), Salem Tamilnadu, India.

\section{A B S T R A C T}

Aim of the study: The aim of this research was to investigate the phytochemical profile, isolate the phytoconsitutuents, Characterised and evaluation of Anti Parkinson activity of ethanolic extract of Indian Medicinal plant of E.cyathophora

Materials and methods: Qualitative phytochemical analysis for their phyto constituents. Ethanol was used to extract the crude bio active compound from whole E. Cyathophora plant. Phenolic derivative were isolated from the ethanolic extract of E. cyathophora by using suitable solvent system and characterised by IR, NMR, MASS spectrophotometric method. The total Neuroprotective activities of E. Cyathophora extract were measured by haloperidol induced experimental animal models.

Result: Qualitative phytochemical analysis showed phenolic compounds, Flavonoids, Alkaloids, glycosides, phenolic compounds and Tannins were in high amounts. The isolated compound Phenolic derivative showed various regions from IR, NMR and MASS the functional groups, mass of the molecule and proton were analysed and confirmed. The effects of E. Cyathophora $(200,400 \mathrm{mg} / \mathrm{kg}$, p.o) were studied using in vivo behavioural parameters like catalepsy, muscle rigidity and locomotor activity and its effects on neurochemical parameters in rats. The increased haloperidol-induced cataleptic scores were significantly $(\mathrm{p}<0.01)$ found to be reduced, with EEEC at dose of $200 \mathrm{mg} / \mathrm{kg}$ and $400 \mathrm{mg} / \mathrm{kg}$ (ip). EEEC administration showed significant increase in dopamine level and significant reduced in serotonin and L-glutamate level. Daily administration of EEEC $(400 \mathrm{mg} / \mathrm{kg})$ significantly improved motor performance.

Conclusion: Overall results the study proved that E. Cyathophora possessed potential components involving in anti Parkinson treatment significantly attenuated the motor defects and also increased the neuro chemical dopamine level.

Keywords: E. cyathophora, Anti-Parkinson's activity, Ethanol extract, L-Dopa, Carbidopa and Haloperidol.

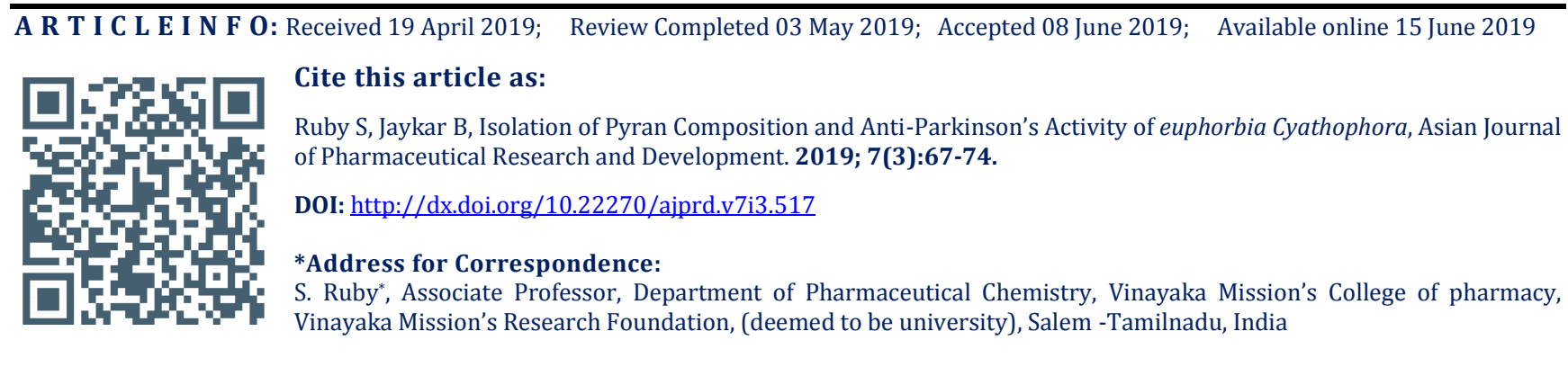

\section{INTRODUCTION}

$\mathrm{P}$ arkinson's disease (PD) is a neurodegenerative brain disorder characterized by progressive loss of dopaminergic and other neurons present in the substantia nigra pars compacta resulting in malfunctioning of the cerebral neuronal systems. Clinically the disease may cause slowness of movement, muscle rigidity, and rest tremor ${ }^{1}$. Pathologically, depletion of dopamine in brain due to the presence of intracytoplasmic inclusions known as Lewy bodies is caused. These pathological changes also observed in the locus coeruleus, pedunculopontine nucleus, raphe nucleus and dorsal motor nucleus of the vagal nerve and sympathetic and parasympathetic postganglionic neurons ${ }^{2}$. Drug management of Parkinson's includes drugs like levodopa, carbidopa, orphenadrine, benztropine, selegiline, pergola which reverses the symptoms of Parkinson's condition but these drugs possess various side effects like respiratory disturbances, hallucinations, discoloration of saliva and urine, dyskinesia convulsions and anxiety, arrhythmia, 
mydriasis, dry mouth, sore throat, and transient dizziness on long term use $\mathrm{u}^{3}$.E. cyathophora is an Euphorbia Lspurge genus belonging to the family Euphorbiaceae.It is the most widely distributed species to Kerala, Andhrapradesh and Tamilnadu. The stem and leaves of $E$. cyathophoraare used to Anti-inflammatory, Anti-diabetic, Antimicrobial, Hepatoprotective, Antioxidant, induce lactation.There have been very few scientific studies conducted on E. cyathophora, however, a comprehensive and exclusive study of the medicinal properties of $E$. cyathophorais still lacking. Hence, the present study aims to analyse the major phytoconstituent in ethanolic extract of the leaves and stems of E. cyathophora.

\section{MATERIALS AND METHODS}

\section{Collection of Plant Material:}

Fresh leaves and stems of E. cyathophora were collected from natural locations in kollihill Tamilnadu region during July-September. This plant was identified and authenticated by ABS Botanical Conservation Research and Training Centre, Kaaripatty. Voucher number AUT/VMCP/105.

\section{Animals:}

Wistar rats $(150-200 \mathrm{~g})$ of either sex were obtained from Srinivasa Enterprises, Bengaluru, India, housed under standard light/dark cycle and fed with standard pellet diet and water ad libitum. The Institutional Animal Ethics Committee, Chennai, India, approved (IAEC, P.Col/11/2017/IAEC/VMCP) experimental protocols and guidelines were followed in conducting the experiments on animals for the purpose of control and supervision of experiments on animals.

\section{Preparation of Extract:}

The leaves were collected, shade dried and coarsely grounded. Coarsely powdered plant material (1000g) was weighed and extracted with 5 lit of solvents like Petroleum ether $\left(60-80^{\circ} \mathrm{C}\right)$, Chloroform and ethanol by successive extraction in a Soxhlet apparatus for $72 \mathrm{hrs}$. After each extraction, the solvent was distilled off and concentrated extract was transferred to previously weighed petri dish and evaporated to dryness at room temperature $\left(45-50^{\circ} \mathrm{C}\right)$ to obtain dried extracts. The extracts were weighed and the percentage yield of the extracts was calculated as follows:

$\%$ of extractiveyield $\left(\frac{\mathrm{w}}{\mathrm{w}}\right)=\frac{\text { Whiet of dried Extract }}{\text { Whight of dried leaves Powder }} X 100$

The yield of ethanol extract was $8.95 \%$ (w/w).

\section{Preliminary Phytochemical Studies:}

Qualitative chemical tests for establishing the chemical composition profile of given extracts were performed using standard methods/protocols ${ }^{4}$ to detect various phyto constituents present ${ }^{4}$.

\section{Detection of Alkaloids}

Alkaloids were detected by following in which solvent free extract $(50 \mathrm{mg})$ was stirred with few $\mathrm{ml}$ of dilute hydrochloric acid and filtered. To few $\mathrm{ml}$ of filtrate, a drop or two of Mayer's reagent was added by the sides of the test tube. A white creamy precipitate formed indicates the test as positive.

\section{Detection of Carbohydrates:}

The extract $(100 \mathrm{mg}$ ) was dissolved in $50 \mathrm{ml}$ of distilled water, filtered and subjected to the following test.

\section{Fehling's test:}

One $\mathrm{ml}$ of filtrate was boiled on water bath with $1 \mathrm{ml}$ each of Fehling's solution I and II. A red precipitate precipitate indicated the presence of sugar.

\section{Benedicts's test:}

To $0.5 \mathrm{ml}$ of Benedicts reagent was added and heated on a boiling water bath for $2 \mathrm{~min}$. a characteristic colored precipitate indicated the presence of sugar.

\section{Detection of glycosides:}

$50 \mathrm{mg}$ of extract was hydrolyzed with concentrated hydrochloric acid for $2 \mathrm{hr}$ on a water bath, filtered and the hydrolysate was subjected to the following test.

\section{Borntrager's test}

To $2 \mathrm{ml}$ of filtrate hydrolysate, $3 \mathrm{ml}$ of chloroform was added and shaken, chloroform layer was separated and $10 \%$ ammonia solution was added to it. Pink color indicated the presence of glycosides.

\section{Detection of saponins: Foam test}

The extract $(50 \mathrm{mg})$ was diluted with distilled water and made up to $20 \mathrm{ml}$ and the suspension was shaken in a graduated cylinder for $15 \mathrm{~min}$. A $2 \mathrm{~cm}$ layer of foam indicated the presence of saponins.

\section{Detection of proteins and amino acids:}

The extract $(100 \mathrm{mg})$ was dissolved in $10 \mathrm{ml}$ of distilled water and filtered through Whatman No.1 filter paper and the filtrate was subjected to tests of proteins and amino acids.

\section{Millon's test}

To $2 \mathrm{ml}$ of filtrate, few drops of millon's reagent were added. A white precipitate indicated the presence of proteins.

\section{Biuret test}

An aliquot of $2 \mathrm{ml}$ of filtrated was treated with on drop of $2 \%$ copper sulphate solution. To this, $1 \mathrm{ml}$ of ethanol (95\%) was added, followed by addition of excess of potassium hydroxide pellets. Pink color in the ethanolic layer indicated the presence of proteins.

\section{Detection of Phenolic Compound:}

\section{Ferric chloride test}

The extract $(50 \mathrm{mg})$ was dissolved in $5 \mathrm{ml}$ of distilled water. To this few drops of neutral $5 \%$ ferric chloride solution were added. A dark green color indicated the presence of phenolic compounds.

\section{Lead acetate test}

The extract $(50 \mathrm{mg})$ was dissolved in $5 \mathrm{ml}$ of distilled water. To this $3 \mathrm{ml}$ of $10 \%$ lead acetate were added. A bulky white precipitate indicated the presence of phenolic compounds.

\section{Isolation of compound A}

Preparation of Admixture of EEEC 
$15 \mathrm{~g}$ of ethanolic extract of E. cyathophorawas admixed with 20 gm silica gel $(60 / 120$ meshes) to get uniform mixing.

\section{Column packing for EEEC}

200 gms of silica gel was taken in a suitable column and packed very carefully without air bubbles using benzene as filling solvent. The column was kept aside for 1 hour and allowed for close packing. Admixture was then added at the top of the stationary phase and started separation of compounds by eluting with solvents of different polarity like Hexane, ethyl acetate and methanol, Dichloromethane All the column fractions were collected separately and concentrated under reduced pressure. Finally the column was washed with ethyl acetate and methanol.

\section{Analysis of the isolated compound from the extract using various analytical techniques}

Isolated compounds were characterized and identified by IR, NMR and GC-MS spectrophotometric methods and chemical structure of the compounds were subsequently elucidated.

\section{Spectral analysis of the compounds using FT-IR}

IR spectra of the compounds isolated from theextracts were recorded using Shimadzu. The spectral resolution for the Shimadzu was $0.25 \mathrm{~cm}^{-1}$, and the spectral data were stored in the database at intervals of $0.5 \mathrm{~cm}^{-1}$ at $4000-2000$ $\mathrm{cm}^{-1}$, and of $0.25 \mathrm{~cm}^{-1}$ at $2000-400 \mathrm{~cm}^{-1}$. The samples were measured by using $\mathrm{KBr}$ disc method.

\section{Spectral analysis of the compounds using ${ }^{1} \mathrm{H}$ NMR}

${ }^{1} \mathrm{H}$ NMR spectra of the compound isolated from the extracts were recorded using a Bruker, USA (400 MHz). The measuring conditions for the most of the spectra were as follows: flip angle of 22.5-30.0 degrees, pulse repetition time of $30 \mathrm{~s}$. The long pulse repetition time and small flip angle is used to ensure precise relative intensities. The ${ }^{1} \mathrm{H}$ NMR chemical shifts were referred to TMS in organic solvents and TSP in $\mathrm{D}_{2} \mathrm{O}$.

\section{Spectral analysis of the compounds using ${ }^{13} \mathrm{C}$ NMR}

${ }^{13} \mathrm{C}$ NMR spectra of the compounds isolated from theextracts were recorded with a Bruker, USA (400 MHz) spectrometer. The measuring conditions for the most of the spectra were as follows: a pulse flip angle of 22.5-45 degrees, a pulse repetition time of 4-7 seconds, and a resolution of $0.025-0.045 \mathrm{ppm}$. The spectra whose spectral codes started with "CDS" were reconstructed from peak positions, intensities, and line widths by assuming all resonance peaks were Lorenz lines. The chemical shift was referred to a TMS for all solvents.

\section{Spectral analysis of the compounds using GC-MS}

Mass spectra of the compounds isolated from the extracts were recorded with Shimadzu USA by the electron impact method where an electron accelerating voltage $75 \mathrm{eV}$ and an ion accelerating voltage of $8-10 \mathrm{nV}$. The reservoir inlet systems were used. The dynamic range for the peak intensities were 3 digits and the accuracy of the mass number was 0.5 .

\section{Acute Oral Toxicity of the Extract:}

Acute oral toxicity study was performed as per OECD 423 guidelines, albino wistar rats $(n=6)$ of either sex selected by random sampling technique were used for acute toxicity study ${ }^{2}$. The animal were kept fasting for overnight providing only water, after which the extract was administered orally at the starting maximum dose level $2000 \mathrm{mg} / \mathrm{kg}$ body weight by oral needle and observed for deaths of overt signs of toxicity $1 / 2,1,2$ and $4 \mathrm{~h}$ after dosing and subsequently once daily for fourteen days. The signs of changes in skin and fur, eyes, mucous membranes, respiratory, circulatory, autonomic and central nervous system, motor activity and behaviour pattern were noted. The toxicity signs of fits, excessive salivation, tremors, diarrhea, lethargy, sleep and coma, as well as the onset of toxicity and signs of toxicity were also noted $^{5}$.

\section{Haloperidol Induced Catalepsy (Model by Elliott and Close in 1990) ${ }^{6}$}

Haloperidol causes dysfunctioning of various neurotransmitters such as acetyl choline, serotonin and GABA and induced catalepsy due to increased oxidative stress. Haloperidol, an antipsychotic drug, blocks central dopamine receptor in striatum and also produces a behavioural immobility and postural cataleptic state in animals characterized by muscle rigidity and failure to correct an externally imposed posture, thus haloperidol induced catalepsy model was selected. The method described by Elliott and Close in 1990 was followed for the anti cataleptic activity.

\section{Experimental Design}

The animals were divided into five groups $(n=6)$. Group I served as vehicle control, group II served as negative control, group III and IV served as test group treated with EEEC (200, $400 \mathrm{mg} / \mathrm{kg}$, i.p.) and group V served as standard L-DOPA+Carbidopa $(100+25 \mathrm{mg} / \mathrm{kg}$, p.o.) respectively. Haloperidol (1mg/kg, i.p.) induced catalepsy was examined at every $30 \mathrm{~min}$ interval for $180 \mathrm{~min}$ using standard bar test. The duration for which the rat retains the forepaws extended and resting on the scale (block-method $0-3.5$ scale) was considered as cataleptic score.

\section{Behavioural Assessment:}

\section{Locomotor Activity:}

The effect on locomotor activity was measured for $10 \mathrm{~min}$ at every $30 \mathrm{~min}$ upto 3 hours using actophotometer. The locomotor activity. It operates on photoelectric cells that are collected in circuit with a counter. can be easily measured by using an actophotometer. When the beam of light falling on the photocell is cutoff by animal, a count is recorded. Actophotometer has either circular or square arena in which animal movements are measured.

\section{Exploratory behaviours}

\section{Head dipping}

The effect on exploratory behaviour (head dipping) was measured for $10 \mathrm{~min}$ at every $30 \mathrm{~min}$ upto 3 hours using hole board.The hole board made of plywood has the size $(60 \mathrm{~cm} \times 60 \mathrm{~cm}, 3 \mathrm{~mm}$ thick). The mat finished of the upper surface avoids reflections which might alter the behaviour of the animal. The board embodies 9 uniformly distributed holes each of $5 \mathrm{~cm}$ in diameter. Each rat was acclimatized for $10 \mathrm{~min}$ and number of holes explored through head plunging acts during the total observation time period were noted. Care has to be taken to avoid 
multiple events (two or more head plunging in quicker session). A fresh exploration was considered when the animal neatly plunged its head once and did something else in between like grooming, taking a short walk etc., before plunging its head for the next time. One animal at a time was tested for each activity.

\section{Line crossing}

The effect on exploratory behaviour (line crossing) was measured for $10 \mathrm{~min}$ at every $30 \mathrm{~min}$ up to 3 hours using hole board. The hole board made of plywood has the size $(60 \mathrm{~cm} \times 60 \mathrm{~cm}, 3 \mathrm{~mm}$ thick). The mat finished of the upper surface avoids reflections which might alter the behaviour of the animal. The board embodies 9 uniformly distributed lines. Each rat was acclimatized for $10 \mathrm{~min}$ and the number of line crossing acts, during the total observation period were counted. Care has to take to avoid multiple events.

\section{Dissection and Homogenization:}

On the day of experiment rats were sacrificed, whole brain was dissected out and separated the subcortical region (including the striatum). Weighed a specific quantity of tissue and was homogenized in $3 \mathrm{ml} \mathrm{HCl}$ butanol in a cool environment. The sample was then centrifuged for $10 \mathrm{~min}$ at $2000 \mathrm{rpm}$. $0.8 \mathrm{ml}$ of supernatant phase was removed and added to an Eppendorf reagent tube containing $2 \mathrm{ml}$ of heptane and $0.25 \mathrm{ml} 0.1 \mathrm{M} \mathrm{HCl}$. After 10min, shake the tube and centrifuged under same conditions to separate two phases. Upper organic phase was discarded and the aqueous phase was used for biochemical estimation ${ }^{7}$.

\section{Biochemical Estimation:}

\section{Dopamine assay}

To $0.02 \mathrm{ml}$ of the $\mathrm{HCl}$ phase, $0.005 \mathrm{ml} 0.4 \mathrm{ml} \mathrm{HCl}$ and $0.01 \mathrm{ml}$ EDTA/ Sodium Acetate buffer ( $\mathrm{pH}$ 6.9) were added, followed by $0.01 \mathrm{ml}$ iodine solution for oxidation. The reaction was stopped after 2 min by the addition of $0.1 \mathrm{ml}$ sodium thiosulphate in $5 \mathrm{M}$ Sodium hydroxide. 10 $\mathrm{M}$ Acetic acid was added $1.5 \mathrm{~min}$ later. The solution was then heated to $100^{\circ} \mathrm{C}$ for $6 \mathrm{~min}$. Excitation and emission spectra were determined using spectrofluorimeter at 330 $375 \mathrm{~nm}$ for the samples at room temperature. Fluorescence (Test - Blank) values, with internal standard $(0.005 \mathrm{ml}$ distilled water and $0.1 \mathrm{ml} \mathrm{HCl}$ butanol to 20ng of dopamine standard), were measured.

\section{Serotinine Estimation}

\section{Serotonin assay}

Tissue extract $0.5 \mathrm{ml}$ and $0.625 \mathrm{ml}$ of OPT (Orthopthaldialdehyde) reagent was heated to $100^{\circ} \mathrm{C}$ for ten min. After the samples reached equilibrium with the ambient temperature, excitation/emission spectra readings at 360-470 $\mathrm{nm}$ were taken.

\section{Estimation of brain glutamate levels by UV assay method}

In this study animals were decapitated after the last behavioural session. The brains were immediately excised and cerebellum discarded. The cortex, striatum and the sub-cortical parts were separated and weighed. The subcortical region of the brain comprised all the remaining parts of the forebrain after dissection of the cerebral cortex and striatum, including the hippocampus, thalamus, hypothalamus, amygdale and other sub-thalamic structures. Spectrophotometer-suitable for precise measurement at 430 $\mathrm{nm}$.

\section{Deproteinization}

Weighed quantity of brain portion was homogenized with 2 parts of perchloric acid by centrifugation for $10 \mathrm{~min}$ at $3000 \mathrm{rpm}$. Pippette out 3.0ml supernatant fluid and make up the $\mathrm{pH}$ to 9 with phosphate solution. Allow the solution to stand for $10 \mathrm{~min}$ in ice bath and filtered using fluted filter paper. Further, solution allowed warming to room temperature, diluted and taking $1.0 \mathrm{ml}$ for the subsequent assays. Wavelength: $340 \mathrm{~nm}$, Light path: $1 \mathrm{~cm}$, Final volume: $3.35 \mathrm{ml}$, Room temperature. For blank measurement, water used as blank instead of sample.

Pipette out $2.00 \mathrm{ml}$ of Glycine-hydrazine buffer, $1.00 \mathrm{ml}$ of Sample, $0.1 \mathrm{ml}$ of ADP solution, $0.2 \mathrm{ml}$ of NAD solution. Mix and read the extinction $\mathrm{E}_{1}$ at $340 \mathrm{~nm}$. Then added 0.05 $\mathrm{ml}$ of GIDH (Glutamate dehydrogenase) solution. Sample and Blank solutions were allowed to stand for $45 \mathrm{~min}$ and measured the extinction $\mathrm{E}_{2}$ at $340 \mathrm{~nm}$. Calculated the difference between $E_{1}$ and $E_{2}$ for sample and blank $(\Delta E)$. $\Delta \mathrm{E}_{\text {sample }}-\Delta \mathrm{E}_{\text {blank }}=\Delta \mathrm{E}_{\text {glutamate }}$ is used for the calculations ${ }^{8}$.

\section{Statistical Analysis}

All the values were expressed as mean \pm SEM. The statistical analysis was carried out using analysis of variance ANOVA (between control and drug treatments), followed by Dunnett's ' $t$ ' test. $\mathrm{P}$ values $<0.05$ considered as significant.

\section{Histopathological Studies:}

Histopathological study on the brains from control and experimental groups were done after fixing with $10 \%$ formalin, embedded in paraffin wax and sliced into longitudinal sections of $5 \mu \mathrm{m}$. Further, Histopathology of these sections was observed using stained with hemotoxylin and eosin dye.

\section{RESULTS AND DISCUSSION}

\section{Phytochemical Screening:}

Table 1: Phytochemical screening of the ethanolic extract of E.Cyathophora.

\begin{tabular}{|l|l|}
\hline Compound & Result \\
\hline Alkaloids & + \\
\hline Glycosides & + \\
\hline Flavonoids & + \\
\hline Phenolic compounds and Tannins & + \\
\hline
\end{tabular}

Acute Toxicity:

The EEEC dose of $2000 \mathrm{mg} / \mathrm{kg}$ was found to be the maximal safe dose with no mortality. Therefore, lower dose of $200 \mathrm{mg} / \mathrm{kg}$ and higher dose of $400 \mathrm{mg} / \mathrm{kg}$ of EEEC were fixed as the study dose.

\section{Effect of EEEC on haloperidol induced catalepsy (0- 3.5 scale)}

The cataleptic scores are depicted in Table 1. There was a significant difference $(\mathrm{P}<0.01)$ between control group (I) and negative control group (II) in catalepsy. The EEEC treated group's shows significant anticataleptic action. EEEC at dose level of $400 \mathrm{mg} / \mathrm{kg}$ particularly, shows 
anticataleptic action comparable to standard drug treatment. There was a significant difference $(\mathrm{P}<0.01)$ between negative control group (II) and EEEC in catalepsy. EEEC at dose level of $400 \mathrm{mg} / \mathrm{kg}$, showed good anticataleptic action at 30, 150, $180 \mathrm{~min}$ after haloperidol challenge.

\section{Effect of EEEC on locomotor activity}

The changes in locomotor activity after haloperidol administration are shown in Table 2. There is a significant $(\mathrm{P}<0.01)$ decrease in locomotor activity in negative control group (II) when compared with the control group (I). EEEC $400 \mathrm{mg} / \mathrm{kg}$ treated animals showed improved locomotor activity when compared with negative control group $(\mathrm{P}<0.01)$. EEEC at a dose of $400 \mathrm{mg} / \mathrm{kg}$ potentiated the locomotor activity of standard drug. All groups were showing significant difference $(\mathrm{P}<0.01)$ when compared with negative control group at all time intervals.

\section{Effect of EEEC on exploratory behaviour}

The exploratory behaviour was expressed by head dippings and line crossings. Head dippings are shown in Table 3 and 4. Negative control group (II) indicated decrease in exploratory behaviour i.e. head dippings and line crossings when compared with control group. The results presented by the EEEC treated groups show significant $(\mathrm{P}<0.01$ and $\mathrm{P}<0.05)$ increase in head dippings and line crossings when compared with negative control group at 90, 120, 150, $180 \mathrm{~min}$ after haloperidol challenge.

\section{Effect of EEEC dopamine levels}

Dopamine levels are significantly $(\mathrm{P}<0.01)$ decreased in negative control group (II) when compared with control group. A significant $(\mathrm{P}<0.01)$ increase in dopamine value is observed in EEEC treated group animals. The results are showing increased dopamine levels in standard drug treated animals also. The results were shown in Table 5.

\section{Effect of EEEC serotonin levels}

The present study shows significant $(\mathrm{P}<0.01)$ increase in serotonin levels in negative control group (II) animals. EEEC treated animals at both doses $200 \mathrm{mg} / \mathrm{kg}$ and 400 $\mathrm{mg} / \mathrm{kg}$ showed significant $(\mathrm{P}<0.05 \& \mathrm{P}<0.01)$ reduction in serotonin levels when compared with negative control group. The results are shown in Table 5.

\section{Effect of EEEC on glutamate levels}

The present study shows significant $(\mathrm{P}<0.01)$ increase in glutamate levels in negative control group animals. EEHP treated animals at both doses $200 \mathrm{mg} / \mathrm{kg}$ and $400 \mathrm{mg} / \mathrm{kg}$ showed significant $(\mathrm{P}<0.05 \quad \& \quad \mathrm{P}<0.01)$ decrease in glutamate level, which is a significant factor in excitotoxicity. The results are shown in Table5.

Table 2: Effect of EEEC on Catalepsy (0-3.5 scale)

\begin{tabular}{|c|c|c|c|c|c|c|}
\hline \multirow[t]{2}{*}{ Group } & \multicolumn{6}{|c|}{ Catalepsy (0-3.5 scale) } \\
\hline & $30 \mathrm{~min}$ & $60 \mathrm{~min}$ & $90 \mathrm{~min}$ & $120 \mathrm{~min}$ & $150 \mathrm{~min}$ & $180 \mathrm{~min}$ \\
\hline I & 0 & 967 & 0 & 0 & 0 & 0 \\
\hline II & $2.90 \pm 0.13^{\mathrm{a}^{* * *}}$ & $3.10 \pm 0.18^{\mathrm{a}^{* * 4}}$ & $3.40 \pm 0.15^{\mathrm{a}^{* *}}$ & $3.60 \pm 0.17^{\mathrm{a}^{* *}}$ & $3.60 \pm 0.15^{\mathrm{a}^{* * *}}$ & $3.60 \pm 0.14^{\mathrm{a}^{* * *}}$ \\
\hline III & $1.95 \pm 0.12^{\text {bns }}$ & $2.64 \pm 0.14^{\text {bns }}$ & $2.89 \pm 0.10^{b^{*}}$ & $2.65 \pm 0.17^{b^{* *}}$ & $2.33 \pm 0.15^{b^{* *}}$ & $1.97 \pm 0.12^{\mathrm{b}^{* *}}$ \\
\hline IV & $1.19 \pm 0.08^{\mathrm{b}^{* *}}$ & $2.14 \pm 0.15^{b^{*}}$ & $2.49 \pm 0.19^{b^{*}}$ & $2.29 \pm 0.14^{\mathrm{b}^{* *}}$ & $1.85 \pm 0.17^{b^{* * *}}$ & $1.27 \pm 0.12^{\mathrm{b}^{* *}}$ \\
\hline $\mathbf{V}$ & $0.80 \pm 0.07^{\mathrm{b}^{* *}}$ & $1.05 \pm 0.10^{\mathrm{b}^{* *}}$ & $1.24 \pm 0.09^{\mathrm{b}^{* *}}$ & $1.05 \pm 0.05^{b^{* *}}$ & $0.65 \pm 0.10^{\mathrm{b} * *}$ & $0.42 \pm 0.12^{\mathrm{b}^{* *}}$ \\
\hline
\end{tabular}

Values are expressed as mean $\pm \mathrm{SEM},{ }^{* *} \mathrm{P}<0.001,{ }^{*} * \mathrm{P}<0.01,{ }^{*} \mathrm{P}<0.05,{ }^{\mathrm{ns}} \mathrm{P}>0.05$

(One way ANOVA followed by Dunnet's test), $n=6$

Table 3: Effect of EEECon Locomotor activity

\begin{tabular}{|c|c|c|c|c|c|c|}
\hline \multirow[t]{2}{*}{ Group } & \multicolumn{6}{|c|}{ Locomotor } \\
\hline & 30 min & $60 \mathrm{~min}$ & $90 \mathrm{~min}$ & $120 \mathrm{~min}$ & $150 \mathrm{~min}$ & $180 \mathrm{~min}$ \\
\hline I & $321.52 \pm 7.24$ & $329.22 \pm 7.14$ & $325.19 \pm 7.62$ & $337.19 \pm 5.33$ & $331.28 \pm 6.17$ & $334.33 \pm 5.29$ \\
\hline II & $29.19 \pm 2.17^{7^{\mathrm{a} *}}$ & $32.33 \pm 2.41^{\mathrm{a}}$ & $30.41 \pm 2.64^{\mathrm{a}^{* *}}$ & $31.22 \pm 1.92^{\mathrm{a}^{* *}}$ & $32.17 \pm 2.74^{\mathrm{a}^{* *}}$ & $34.28 \pm 2.52^{\mathrm{b}^{* *}}$ \\
\hline III & $77.29 \pm 3.41^{\mathrm{b}^{*}}$ & $126.67 \pm 4.33^{\mathrm{b}^{* *}}$ & $133.27 \pm 4.54^{\mathrm{b}^{* * *}}$ & $154.22 \pm 4.28^{\mathrm{b}^{* *}}$ & $172.87 \pm 4.64^{\mathrm{b}^{* *}}$ & $201.52 \pm 4.33^{\mathrm{b}^{* *}}$ \\
\hline IV & $91.24 \pm 3.27^{b * *}$ & $145.21 \pm 4.12^{\mathrm{b}^{* *}}$ & $152.17 \pm 4.52^{b^{* *}}$ & $174.29 \pm 4.22^{\mathrm{b}^{* *}}$ & $195.67 \pm 4.52^{b^{* *}}$ & $222.17 \pm 4.74^{\mathrm{b} * *}$ \\
\hline $\mathbf{V}$ & $128.05 \pm 6.27^{\mathrm{b}^{* *}}$ & $228.33 \pm 6.47^{\mathrm{b}^{*}}$ & $244.17 \pm 6.54^{\mathrm{b}^{*}}$ & $267.22 \pm 6.14^{\mathrm{b}^{*}}$ & $272.19 \pm 5.21^{\mathrm{b}^{*}}$ & $312.64 \pm 6.39^{\mathrm{b}^{*}}$ \\
\hline
\end{tabular}

Values are expressed as mean $\pm \mathrm{SEM}, *^{* *} \mathrm{P}<0.001, * * \mathrm{P}<0.01, * \mathrm{P}<0.05,{ }^{\mathrm{ns}} \mathrm{P}>0.05$ (One way ANOVA followed by Dunnet's test), $\mathrm{n}=6$

Table 4: Effect of EEEC on Exploratory Behaviour - Head Dipping

\begin{tabular}{|c|c|c|c|c|c|c|}
\hline \multirow[t]{2}{*}{ Group } & \multicolumn{6}{|c|}{ Head Dipping Behaviour } \\
\hline & $30 \mathrm{~min}$ & $60 \mathrm{~min}$ & $90 \mathrm{~min}$ & 120 min & $150 \mathrm{~min}$ & 180 min \\
\hline I & $8.52 \pm 0.30$ & $7.84 \pm 0.43$ & $8.22 \pm 0.54$ & $7.72 \pm 0.42$ & $7.52 \pm 0.42$ & $7.41 \pm 0.21$ \\
\hline II & $0.49 \pm 0.22^{\mathrm{a}^{* *}}$ & $0.45 \pm 0.31^{\mathrm{a}^{\mathrm{k} *}}$ & $0.21 \pm 0.17^{\mathrm{a}^{* *}}$ & $0.52 \pm 0.22^{\mathrm{a}^{* *}}$ & $0.37 \pm 0.21^{\mathrm{a}^{* *}}$ & $0.59 \pm 0.22^{\mathrm{a}^{* * *}}$ \\
\hline III & $2.92 \pm 0.52^{b^{*}}$ & $4.85 \pm 0.33^{b^{* *}}$ & $5.69 \pm 0.14^{\mathrm{b}^{* *}}$ & $6.52 \pm 0.37^{\mathrm{b}^{* *}}$ & $6.96 \pm 0.28^{\mathrm{b}^{* *}}$ & $7.12 \pm 0.33^{b^{*}}$ \\
\hline IV & $4.22 \pm 0.32^{\mathrm{b}^{* *}}$ & $5.96 \pm 0.12^{\mathrm{b}^{* *}}$ & $7.14 \pm 0.41^{b^{* *}}$ & $7.33 \pm 0.24^{\mathrm{b}^{* *}}$ & $7.89 \pm 0.28^{\mathrm{b}^{* *}}$ & $8.27 \pm 0.24^{\mathrm{b} * *}$ \\
\hline $\mathbf{V}$ & $5.21 \pm 0.22^{\mathrm{b}^{* * *}}$ & $6.54 \pm 0.41^{\mathrm{b}^{* * *}}$ & $7.69 \pm 0.33^{b^{* * *}}$ & $8.12 \pm 0.28^{\mathrm{b}^{* *}}$ & $8.29 \pm 0.51^{b^{* * *}}$ & $8.69 \pm 0.33^{\mathrm{b}^{* *}}$ \\
\hline
\end{tabular}


Table 5: Effect of EEHP on Exploratory Behaviour - Line Crossing

\begin{tabular}{|l|l|l|l|l|l|l|}
\hline \multirow{2}{*}{ Group } & \multicolumn{5}{|c|}{ Line Crossing Behaviour } \\
\cline { 2 - 7 } & $\mathbf{3 0}$ min & $\mathbf{6 0}$ min & $\mathbf{9 0}$ min & $\mathbf{1 2 0}$ min & $\mathbf{1 5 0}$ min & $\mathbf{1 8 0 ~ m i n}$ \\
\hline I & $84.33 \pm 3.69$ & $82.67 \pm 4.41$ & $85.49 \pm 4.57$ & $81.22 \pm 3.67$ & $88.42 \pm 4.33$ & $89.17 \pm 4.17^{\mathrm{a}^{* *}}$ \\
\hline II & $5.29 \pm 0.54^{\mathrm{a}^{* *}}$ & $4.52 \pm 0.33^{\mathrm{a}^{* *}}$ & $4.19 \pm 0.41^{\mathrm{a}^{* *}}$ & $3.54 \pm 0.29^{\mathrm{a}^{* *}}$ & $3.22 \pm 0.57^{\mathrm{b}^{* *}}$ & $3.64 \pm 0.46^{6^{w *}}$ \\
\hline III & $14.17 \pm 1.09^{\mathrm{bns}}$ & $23.54 \pm 3.54^{\mathrm{b}^{* *}}$ & $30.29 \pm 3.72^{\mathrm{b}^{* *}}$ & $41.19 \pm 3.84^{\mathrm{b}^{* *}}$ & $50.22 \pm 3.21^{\mathrm{b}^{* *}}$ & $56.33 \pm 3.24^{\mathrm{b}^{\mathrm{k} *}}$ \\
\hline IV & $29.17 \pm 3.54^{\mathrm{b}^{* *}}$ & $44.19 \pm 3.22^{\mathrm{b}^{* *}}$ & $49.67 \pm 3.45^{\mathrm{b}^{* *}}$ & $52.13 \pm 4.17^{\mathrm{b}^{* *}}$ & $62.57 \pm 4.62^{\mathrm{b}^{* *}}$ & $65.39 \pm 3.14^{\mathrm{b}^{\mathrm{*} *}}$ \\
\hline V & $39.54 \pm 3.13^{\mathrm{b}^{* *}}$ & $59.22 \pm 4.80^{\mathrm{b}^{* *}}$ & $68.44 \pm 4.46^{\mathrm{b}^{* *}}$ & $74.19 \pm 4.75^{\mathrm{b}^{* *}}$ & $77.69 \pm 4.49^{\mathrm{b}^{* *}}$ & $79.54 \pm 5.28^{\mathrm{b}^{\mathrm{k} *}}$ \\
\hline
\end{tabular}

Values are expressed as mean \pm SEM ${ }^{* * *} \mathrm{P}<0.001,{ }^{* *} \mathrm{P}<0.01,{ }^{*} \mathrm{P}<0.05,{ }^{\mathrm{n} s} \mathrm{P}>0.05$ (One way ANOVA followed by Dunnet's test), $\mathrm{n}=6$

Table 6: Effect of EEEC on brain Neurotransmitter Levelsin chronic haloperidol treated rats

\begin{tabular}{|l|l|l|l|l|}
\hline Groups & Treatment & $\begin{array}{l}\text { Dopamine } \\
(\mathbf{p g} / \text { mg tissue })\end{array}$ & $\begin{array}{l}\text { Serotonin } \\
(\mathbf{p g} / \mathbf{m g} \text { tissue })\end{array}$ & $\begin{array}{l}\text { L-Glutamate } \\
(\mu \text { mol/gm tissue })\end{array}$ \\
\hline I & Control & $754.69 \pm 12.47$ & $274.33 \pm 5.17$ & $74.19 \pm 3.22$ \\
\hline II & Negative control (Haloperidol) & $267.33 \pm 10.14^{\mathrm{a}^{* *}}$ & $412.27 \pm 4.67^{\mathrm{a}^{* *}}$ & $52.17 \pm 2.33^{\mathrm{a}^{* *}}$ \\
\hline III & EEEC $(200 \mathrm{mg} / \mathrm{kg})$ & $514.51 \pm 7.49^{\mathrm{b}^{* *}}$ & $372.12 \pm 6.47^{\mathrm{b}^{*}}$ & $55.84 \pm 3.69^{\mathrm{bns}}$ \\
\hline IV & EEEC $(400 \mathrm{mg} / \mathrm{kg})$ & $568.64 \pm 8.22^{\mathrm{b}^{* *}}$ & $353.22 \pm 6.14^{\mathrm{b}^{* *}}$ & $59.44 \pm 2.97^{\mathrm{b}^{*}}$ \\
\hline $\mathbf{V}$ & $\begin{array}{l}\text { L-DOPA }(100 \mathrm{mg} / \mathrm{kg})+\text { Carbidopa }(25 \mathrm{mg} / \mathrm{kg}) \text { as } \\
\text { Standard }\end{array}$ & $682.19 \pm 10.22^{\mathrm{b}^{* *}}$ & $307.58 \pm 4.69^{\mathrm{b}^{* *}}$ & $69.22 \pm 2.54^{\mathrm{b}^{* *}}$ \\
\hline
\end{tabular}

Values are expressed as mean $\pm \mathrm{SEM},{ }^{* * *} \mathrm{P}<0.001,{ }^{* *} \mathrm{P}<0.01,{ }^{*} \mathrm{P}<0.05,{ }^{\mathrm{n}} \mathrm{P}>0.05$ (One way ANOVA followed by Dunnet's test), $\mathrm{n}=6$

\section{Histopathological studies on brain}

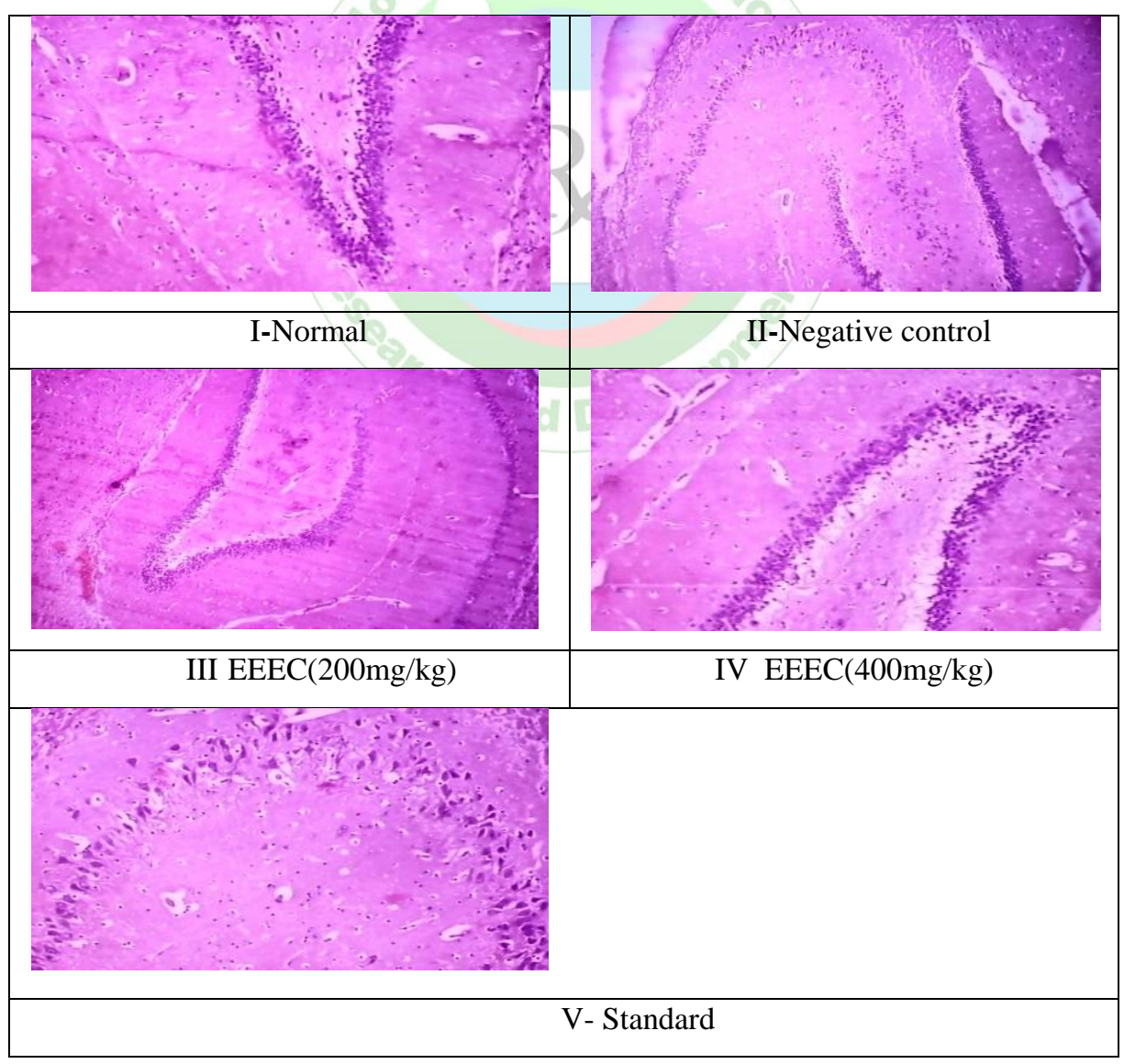

\section{Characterization of Compound EC I}

The isolated compound is light yellowish brown in colour, solid (323 mg), soluble in methanol, ethanol and water. Melting point was found to be $178-183^{\circ} \mathrm{C}$. The mass of compound was found as $194[\mathrm{M}+1]$. 


\begin{tabular}{|l|l|l|}
\hline S. No & ${\text { Wave numbers } \mathbf{~ c m}^{-1}}^{-1}$ & Type \\
\hline 1. & 3395 & OH \\
\hline 2. & 3013 & C-H \\
\hline 3. & 1698 & C=0 \\
\hline 4. & 1412 & C-H \\
\hline 5. & 1058 & C-O-C \\
\hline
\end{tabular}

IR $v^{\text {cm-1 }}:(\mathrm{KBr})$ Pressed pellet technique (EC I)

${ }^{1} \mathrm{HNMR}$ (Acetone - $\mathrm{d}_{6},{ }_{400 M H_{\mathrm{Z}}}$ ) ppm

$\delta 3.87(\mathrm{~d}, 1 \mathrm{H}, \mathrm{C} 2$ - H), 3.46 (d, 1H, C6 - H), 3.35 (t, 1H, C3 - H), $3.23(\mathrm{t}, 1 \mathrm{H}, \mathrm{C} 4-\mathrm{H}), 3.15(\mathrm{t}, 1 \mathrm{H}, \mathrm{C} 5$ - H).

${ }^{13}$ CNMR: (Acetone-d $6,400 \mathrm{MH}_{\mathrm{Z}}$ ), ppm

$\delta 165$ C (C - 7), 95 C (C - 2), 75.89 C (C - 4), 75.70 C (C - 3), 70 C (C - 5), 69.55 C (C - 6).

Properties of isolated compound EC I

\begin{tabular}{|l|l|}
\hline Name & Compound A \\
\hline Molecular formula & $\mathrm{C}_{6} \mathrm{H}_{10} \mathrm{O}_{7}$ \\
\hline Melting point & $185-191^{\circ} \mathrm{C}$ \\
\hline Mass (m/z) & $194(\mathrm{M}+1)$ \\
\hline Colour & Yellowish brown \\
\hline Nature & Solid \\
\hline Solubility & Soluble in methanol, ethanol and water \\
\hline TLC studies & Methanol: DCM ( $\mathrm{R}_{\mathrm{f}}$ Value 0.21$) 80: 20(\mathrm{v} / \mathrm{v})$ \\
\hline
\end{tabular}

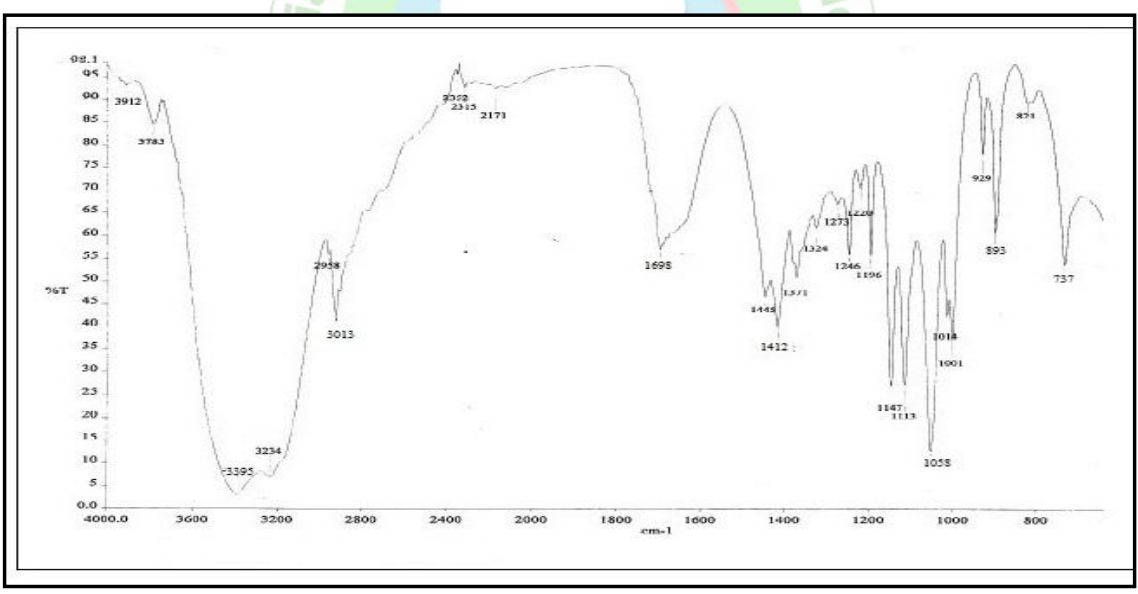

Figure 1: IR Spectum of EC 1

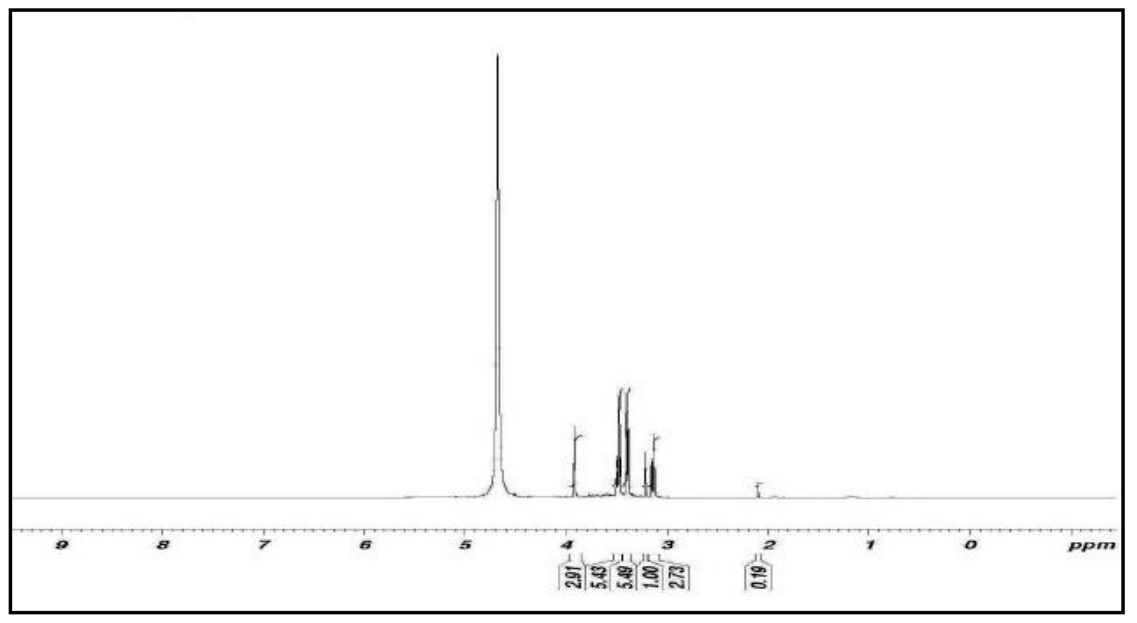

Figure 2: HNMR Spectrum of EC1 


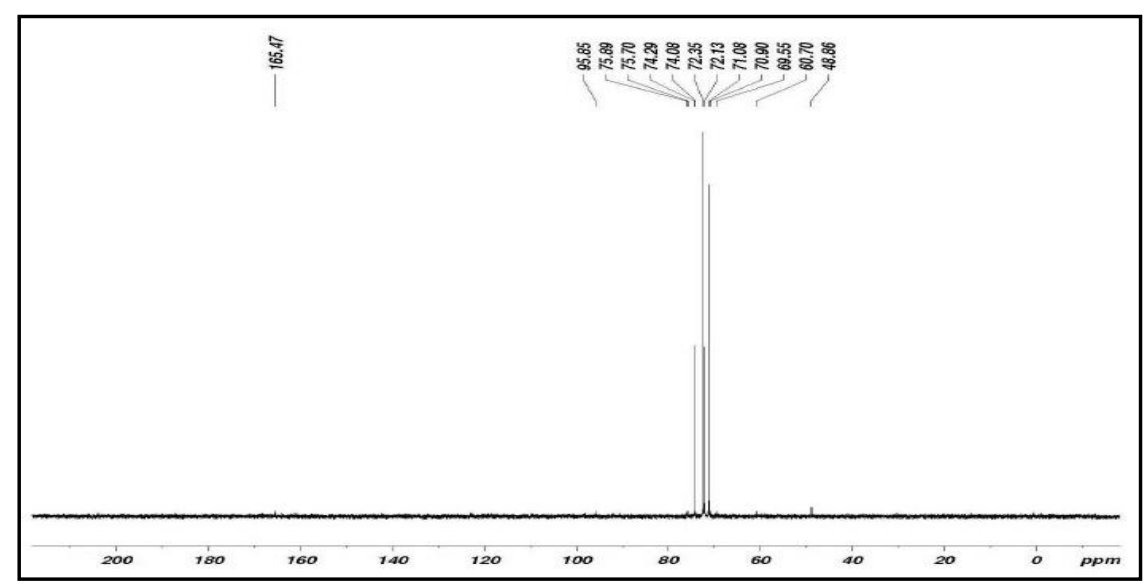

Figure 3: $\mathrm{C}^{13} \mathrm{NMR}$ of structure EC 1

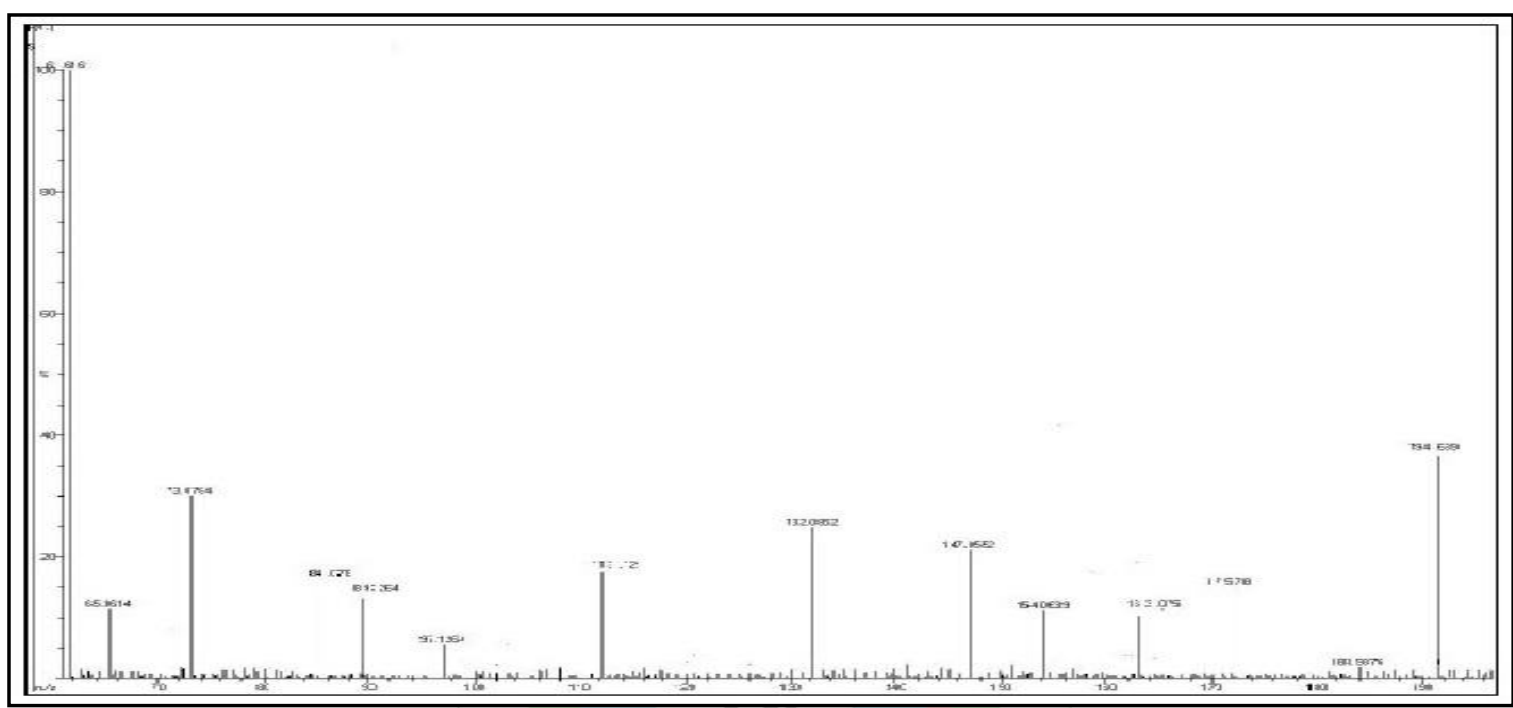

Figure 4: MASS Spectrum of EC1

\section{CONCLUSION}

From these results of the present study, it was understood that E. Cyathophora has higher anti Parkinson activity it may be understood from the variations in the profiles of the functional groups and phytochemical of the plants. In view of the above facts, we are concluding that ethanolic extract of plant showed to a Euphorbia cyathophora promising effect in animals with parkinson's disease. And we appreciate further detailed molecular docking studies with this drug in anti-parkinson's pharmacology and toxicology responsible for Neuroprotective effect.

\section{ACKNOWLEDGEMENT}

I submit my sincere and heartful gratitude to my respectable guide Dr. B. Jaykar, M. Pharm, Ph.D, Prof., Vinayaka Mission's college of Pharmacy; Salem. whose guidance was unforgettable and incomparable. The inspiration, impressive and innovative ideas as well as her constructive suggestions, untiring efforts and timely help have made the materialization of my research work.

\section{REFERENCE}

1. Leenders KL and WH Oertel, "Parkinson's disease; Clinical signs and symptoms, neural mechanisms, Positron emission tomography,
2. and therapeutic interventions," Neural plasticity. 2001; 8(1-2):99110.

3. Braak H, Rub U, Gai WP, and Del K tredici, "Idiopathic Parkinson's disease: Possible routes by which Vulnerable neuronal types may be subject to neuroinvasion by an unknown pathogen," Journal of Neural transmission, 2003; 110(5):517-536.

4. Karch AM , Focus on Nursing Pharmacology, Lippincott Williams and wilkins, Philadelphia, Pa, USA, 2009; $5^{\text {th }}$ edition.

5. Harbone, JB. Phytochemical Methods. Chapman and Hall Ltd, London.1973; 149:188.

6. Schlede E, Miscke U, Diener W, Kayser D. The International Validation study of the Acute Toxic Class method (oral). Archive Toxicology. 1994; 69:659-670.

7. Elliot PJ. and SP. Close, "Neuroleptic- induced catalepsy as a model of Parkinson's disease I. Effect of dopaminergic agents, "Journal of Neural Transmission. Parkinson's disease and Dementia section, 1990; 2(2):79-89.

8. Vinod BK, Shankar RP, Karan RS, Handu SS. "Effect of the 5HT3 receptor antagonist ondansetron on amphetamine induced hyperactivity on Stereotypes in rats". Ind. J Physiol Pharmacol 2000; 44(3): 355-358.

9. Schlumpf M, Lichtensteiger W, Langermann H, Waser PG, Heffi FA. "Fluori metric micro method for the simultaneous determination of serotonin, noradrenaline and dopamine in milligram amount of brain tissue". Biochemical pharmacology 1974; 23:2337-2446. 